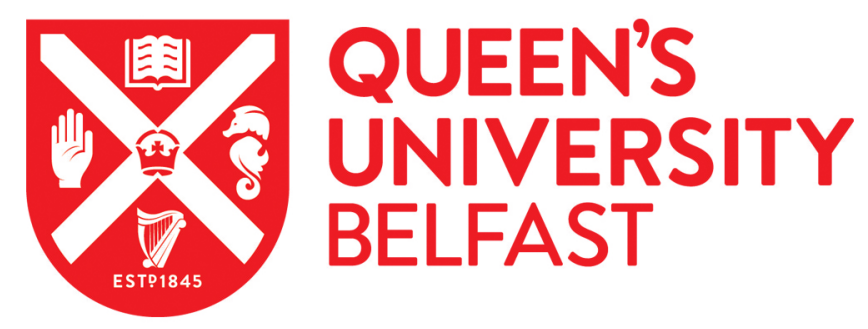

\title{
Effect of DPYD, MTHFR, ABCB1, XRCC1, ERCC1 and GSTP1 on chemotherapy related toxicity in colorectal carcinoma
}

Puerta-García, E., Urbano-Pérez, D., Carrasco-Campos , M. I., Perez-Ramirez, C., Segura-Pérez , A., Calleja Hernandez, M. A., \& Cañadas-Garre, M. (2020). Effect of DPYD, MTHFR, ABCB1, XRCC1, ERCC1 and GSTP1 on chemotherapy related toxicity in colorectal carcinoma. Surgical Oncology.

https://doi.org/10.1016/j.suronc.2020.09.016

Published in:

Surgical Oncology

Document Version:

Peer reviewed version

Queen's University Belfast - Research Portal:

Link to publication record in Queen's University Belfast Research Portal

Publisher rights

(C) 2020 Elsevier Ltd. All rights reserved.

This work is made available online in accordance with the publisher's policies. Please refer to any applicable terms of use of the publisher.

\section{General rights}

Copyright for the publications made accessible via the Queen's University Belfast Research Portal is retained by the author(s) and / or other copyright owners and it is a condition of accessing these publications that users recognise and abide by the legal requirements associated with these rights.

Take down policy

The Research Portal is Queen's institutional repository that provides access to Queen's research output. Every effort has been made to ensure that content in the Research Portal does not infringe any person's rights, or applicable UK laws. If you discover content in the Research Portal that you believe breaches copyright or violates any law, please contact openaccess@qub.ac.uk. 
INDEX

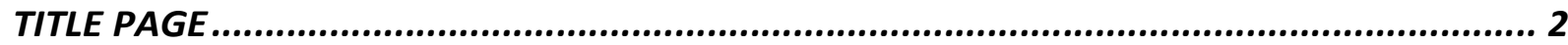

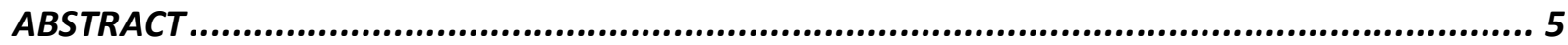

INTRODUCTION

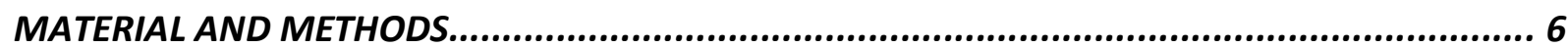

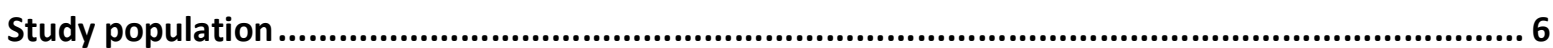

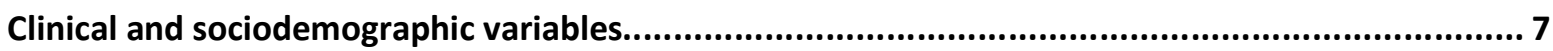

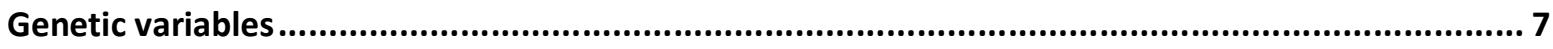

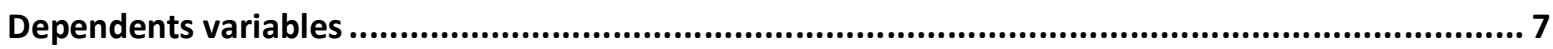

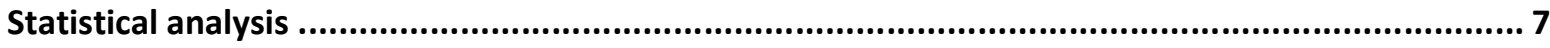

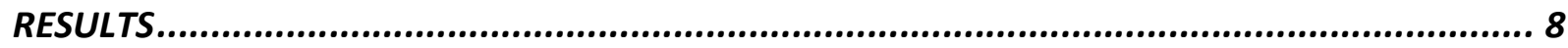

Patients Characteristics......................................................................................... 8

Influence of clinical and genetic variables on treatment toxicity in first line of treatment...............9

Clinical and genetic variables influence on treatment toxicity in second line of treatment ............. 10

Clinical and genetic variables influence on treatment toxicity with 5-Fluorouracil in first line ........ 11

Clinical and genetic variables influence on treatment toxicity with Capecitabine in first line.......... 12

Clinical and genetic variables influence on treatment toxicity with Oxaliplatin in first line ............. 13

Clinical and genetic variables influence on treatment toxicity with Irinotecan in second line ......... 14

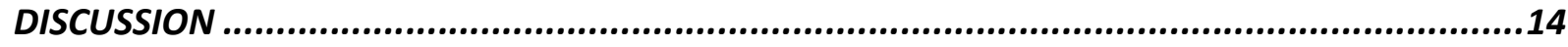

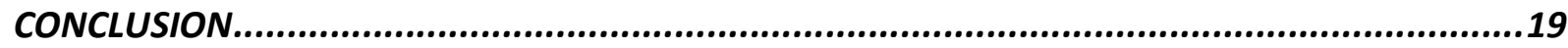

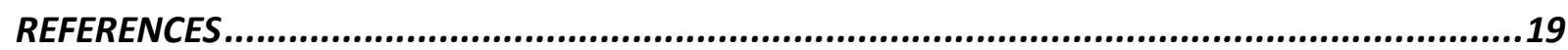

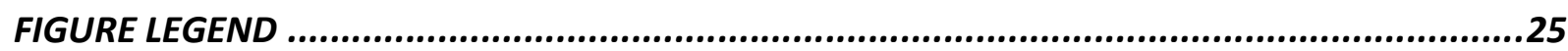

Figure 1. Study population divided by chemotherapeutic treatment line. ..........................25 
TITLE PAGE

TITLE

EFFECT OF DPYD, MTHFR, ABCB1, XRCC1, ERCC1 AND GSTP1 ON CHEMOTHERAPY RELATED TOXICITY IN COLORECTAL CARCINOMA

\section{AUTHORS NAMES AND AFFILIATIONS}

Puerta-García Elena ${ }^{1}$, Urbano-Pérez David ${ }^{2}$, Carrasco-Campos María Isabel ${ }^{3}$, Pérez-Ramírez Cristina ${ }^{4 *}$, Segura-Pérez Ana ${ }^{5}$, Calleja-Hernández Miguel Ánge ${ }^{6}$, Cañadas-Garre Marisa ${ }^{7 *}$

* Both are authors for correspondence

${ }^{1} \mathrm{Ph}$ Student

Pharmacy Service, Pharmacogenetics Unit. University

Hospital Virgen de las Nieves, Granada

Av. de las Fuerzas Armadas, 2, 18014 Granada, Spain

Email: elenapuert@gmail.com

${ }^{2} \mathrm{Ph}$ Student

Pharmacy Service, Pharmacogenetics Unit. University

Hospital Virgen de las Nieves, Granada

Av. de las Fuerzas Armadas, 2, 18014 Granada, Spain

Email: davidurbanopv@gmail.com

${ }^{3}$ Ph Student

Pharmacy Service, Pharmacogenetics Unit. University

Hospital Virgen de las Nieves, Granada

Av. de las Fuerzas Armadas, 2, 18014 Granada, Spain

${ }^{4}$ Department of Social Pharmacy, Faculty of Pharmacy.

University of Lisbon

Av. Prof. Gama. Pinto.1600-083 Lisbon, Lisboa e Vale do Tejo- Portugal

Email: cperezramirez87@gmail.com

Email:mariaisabelcarrascocampos@gmail.com

${ }^{5}$ Laboratory technician

Pathology Department, Universitary Hospital Campus de la Salud, Granada

Av. de la Investigación, s/n, 18016 Granada

Email: anichu29@hotmail.com

${ }^{6} \mathrm{PhD}$. Chief of Department of Pharmacy, Unidad de Gestion Clinica (UGC).

Department University Hospital Virgen Macarena, Sevilla 
Calle Dr. Fedriani, 3, 41009 Sevilla, Spain

Email: mangel.calleja.sspa@juntadeandalucia.es

${ }^{7}$ Epidemiology and Public Health Research Group Centre for Public Health, Queen's

University of Belfast

Belfast. Northern Ireland, United Kingdom

Telephone: +44 (0)2890 976002

Fax: $+44(0) 2890235900$

Email: m.canadasgarre@qub.ac.uk

\section{KEYWORDS}

CHEMOTHERAPY TREATMENT

COLORECTAL CANCER

TOXICITY

POLYMORPHISMS

WORD COUNT (excluding references and figure legends):

Abstract: $\quad 235$ words

Main Text: 4933 words

\section{ETHICAL APPROVAL AND CONSENT TO PARTICIPATE}

Samples were provided by the Biobank of Andalusia (Collection Code: 19150007). The study was approved by the HUVN Ethics and Research Committee, and was conducted according to the Declaration of Helsinki.

\section{CONSENT TO PUBLISH}

I, on behalf of all the authors of this work, give our consent to publish

\section{DATA AVAILABILITY}

All data were confidentially recorded at University Hospital. We are not authorized to share our database or make it public.

\section{CONFLICTS OF INTEREST}

The authors declare no potential conflicts of interest.

\section{FUNDING}

The Hospital Universitario Virgen de las Nieves Biobank was supported by grants funded by FEDER funds (EU) from the Instituto de Salud Carlos III (PT13/0010/0039).

\section{AUTHORS' CONTRIBUTIONS}

The list of the coauthors includes all appropriate persons, and all persons listed have contributed in some way to the design, implementation and/or analysis, interpretation and reporting of the study. 


\section{ACKNOWLEDGEMENTS}

The results of this investigation are part of the doctoral thesis presented by Elena Puerta- García at the University of Granada. 


\section{ABSTRACT}

ABCB1, DPYD, MHTFR, XRCC1, ERCC1, GSTP1 and UGT1A1 genetic variants affect proteins related to CRC chemotherapy toxicity

A retrospective cohort study was conducted in 194 CRC patients.

In first line treatment, DPYD rs17376848 AG genotype was associated with hematological toxicity $(\mathrm{OR}=4.85 ; \mathrm{p}=0.03)$; GSTP1 G-allele $(\mathrm{OR}=3.01 ; \mathrm{p}=0.005)$ and MTHFR $\mathrm{rs} 1801133$ T allele $(\mathrm{OR}=2.51$; $p=0.03$ ) with respiratory toxicity; GSTP1 G-allele with cardiovascular toxicity (OR=4.05; $p=0.01$ ); ERCC1 rs11615 GG genotype with neurological toxicity ( $O R=3.98 ; p=0.01)$ and with asthenia $(\mathrm{OR}=2.91 ; \mathrm{p}=0.08) ; \quad \mathrm{XRCC1} \mathrm{rs} 1799782 \mathrm{~T}$ allele $(\mathrm{OR}=0.31 ; \mathrm{p}=0.03)$ and GSTP1 G-allele $(\mathrm{OR}=1.81 ; \mathrm{p}=0.01$ ) with cutaneous toxicity. In second line treatment, XRCC1 rs1799782 T-allele was associated with asthenia ( $O R=0.17 ; p=0.03)$ and $X R C C 1$ rs 25487 T-allele with gastrointestinal toxicity $(O R=3.03 ; p=0.005)$. After stratifying by treatment, in the 5-Fluorouracil group, the DPYD rs17376848 AG genotype was associated with hematological toxicity (OR=2.76; $p=0.003), A B C B 1$ rs1045642 T-allele with the need of treatment adjustment due to toxicity ( $O R=3.06 ; p=0.01$ ), and rs1045642 CC genotype with gastrointestinal toxicity ( $O R=5.80 ; p=0.03)$. In the capecitabine group, the MTHFR rs1801131 CC genotype was associated with asthenia (OR=3.48; $p=0.009)$. In the oxaliplatin group, rs1045642 TT genotype was associated with the need to adjust treatment $(\mathrm{OR}=0.32 ; \mathrm{p}=0.02)$, ERCC1 $\mathrm{rs} 11615 \mathrm{GG}$ genotype with asthenia ( $\mathrm{OR}=3.01 ; \mathrm{p}=0.01$ ) and $\mathrm{rs} 1615 \mathrm{GSTP} 1$ GG genotype with respiratory toxicity ( $O R=5.07 ; p=0.009)$.

ABCB1 rs1045642 T-allele reduces the need for treatment modification with both 5FU and oxaliplatin. Although several biomarkers predicted different toxic effects, they cannot be considered as risk factors for severe toxicity.

\section{INTRODUCTION}

Surgery is the treatment of choice in colorectal cancer (CRC) early stages. From stage III, chemotherapy is recommended as adjuvant treatment after surgery, or as only treatment if surgery is not possible. The main drug in CRC chemotherapy treatment is 5-Fluorouracil (5FU) or Capecitabine, its oral prodrug, used either in monotherapy or more frequently, in combination with Oxaliplatin and/or Irinotecan [1]. Chemotherapy toxic effects are numerous and, in some cases, can compromise the patient's life. However, there is variability in the intensity of adverse reactions, being even mild or even non-existent in a significant percentage of patients [2-5]. As toxicity increases with the time of exposure to the chemotherapeutic agent, it seems reasonable that 
genetic variants affecting the correct functioning of proteins involved in drug's ADME process (absorption, distribution, metabolism and elimination) are, in some way, related to drug's toxicity. Some genetic variants of the DPYD gene [6-13], that encodes dihydropyrimidine dehydrogenase (DPD), the enzyme responsible for the hepatic metabolism of 5FU and capecitabine, have been related to the fluoropirimidines toxicity. The variants that deeply decrease the enzyme activity are rs3918290 (DPYD*2A), rs55886062 (DPYD*13) and rs67376798, while the effect of rs17376848 results in a moderate reduction [14].

The ATP-binding cassette sub-family $B$ member 1 ( $A B C B 1)$ is a transport protein, encoded by $A B C B 1$ gene [15], expels xenobiotics (as toxins or drugs) previously absorbed. Some tumor cells overexpress a large amount $A B C B 1$, which is an important cause of the multiresistance of some tumors to chemotherapy $[16,17]$. The rs 1045642 polymorphism of $A B C B 1$ [18-20] have been broadly related to the toxicity of these drugs.

The MTHFR gene encodes an enzyme called methylenetetrahydrofolate reductase. This enzyme, catalyzes the conversion of 5,10-methylenetetrahydrofolate to 5-methyltetrahydrofolate, and plays an important role in DNA synthesis. The TT and CT genotypes of rs 1801833 polymorphism in MTHFR have been associated with increased risk of diarrhea, mucositis and neutropenia [21], whereas the CC genotype has been described as a risk factor for severe toxicity after 5FU treatment in CRC patients [22].

X-ray repair cross complementing 1 (XRCC1) and Excision Repair Cross-Complementing group 1 (ERCC1) are proteins encoded by the gene of the same name whose function is to repair DNA damaged by ionizing radiation and alkylating agents such as oxaliplatin and irinotecan $[23,24]$.

GSTP1 (Glutathione S-Transferase) is an enzyme that plays an important role in the detoxification of xenobiotics, encoded in humans by GSTP1 gene [25]. Polymorphisms in genes XRCC1, ERCC1 and GSTP1 gene have been associated with toxicity to both oxaliplatin and irinotecan schemes [18,20,26-29]

The aim of this study was to investigate the influence of DPYD, MTHFR, ABCB1, ERCC1, XRCC1 and GSTP1 polymorphisms on the any kind of toxic effects induced by chemotherapy in CRC patients.

\section{MATERIAL AND METHODS}

A retrospective observational cohort study was conducted.

\section{Study population}

Data were obtained from 194 CRC patients treated at the Oncology Unit of the Hospital Universitario 
Virgen de las Nieves (HUVN). New toxicity data were collected from 86 patients who received a second line of treatment at the same hospital. All patients were Caucasians older than 18 years. Exclusion criteria included incomplete clinical history or synchronous neoplasm different from CRC. The study was approved by the HUVN Ethics and Research Committee, and was conducted according to the Declaration of Helsinki. All data were confidentially recorded.

\section{Clinical and sociodemographic variables}

Variables collected were: chemotherapy treatment regimen, toxicity according to the National Cancer Institute's Common Terminology Criteria for Adverse Events (NCl-CTCAE v. 4.0) [30], diagnosis, date and age of diagnosis, sex, tumor size, TNM tumor staging according to the American Joint Committee of Cancer (AJCC) classification [31], histopathology, date of surgery, date of death (if applicable), Eastern Cooperative Oncology Group (ECOG) Performance Status and modification of chemotherapy treatment (dose reduction, delay or suspension).

\section{Genetic variables}

Samples of paraffin-embedded healthy tissue from surgical resection were provided by the Biobank of Andalusia (Collection Code: 19150007). Only healthy tissue was used, since we were looking for polymorphisms in the germline. DNA was extracted using the QIAamp DNA Mini Kit, following manufacturer's instructions and stored at $-40^{\circ} \mathrm{C}$. The following polymorphisms were analyzed by Real-Time PCR with TaqMan ${ }^{\circledR}$ probes: DPYD rs3918290, rs55886062, rs67376798 and rs17376848, ABCB1 rs1045642, MTHFR rs1801133 and rs1801131, XRCC1 rs25487 and rs1799782, ERCC1 rs11615 and rs3212986, GSTP1 rs1695 and UGT1A1 rs4148323. As quality control of the methodology, twenty percent of samples were confirmed by Sanger sequencing.

\section{Dependents variables}

Toxicity grade (1-2 vs 3-4) and type (asthenia, neurological, hematological, cutaneous, gastrointestinal, cardiovascular, respiratory or infusional reaction) were analyzed. In the analysis stratified by treatment subgroups, the modification of treatment was also evaluated (dose reduction, delay or suspension due to toxicity).

\section{Statistical analysis}

The software used was R 2.3.0 (29). Shapiro-Wilks test determined the normality of the variables. Non-normally distributed quantitative variables were described by medians and interquartile range, qualitative variables as frequencies. Pearson chi-square/Fisher for qualitative and Wilcoxon tests for 
quantitative were used for bivariate analysis. Bonferroni correction was applied (significance threshold: $p<(0.05 /$ number of SNPs). Significance level for any other test was $p<0.05$. Multivariate analysis was carried out using a logistic regression model including all bivariate associations with $p$ $<0.1$ as potential confounders. Hardy-Weinberg equilibrium and disequilibrium linkage was performed using PLINK v1.90b4.5 [32]. Allelic population frequencies were compared with the Iberian Population in Spain [33]. The genetic models were defined as follows: genotypic (major allele homozygotes vs. heterozygotes vs. minor allele homozygotes), allelic (minor allele vs. major allele), trend (major allele homozygotes vs. heterozygotes vs. minor allele homozygotes), dominant (minor allele homozygotes plus heterozygotes vs. major allele homozygotes) and recessive (minor allele homozygotes vs. heterozygotes plus major allele homozygotes) [34]. In the total sample (194 firstline patients) and (86 second-line patients), toxicity to any CRC chemotherapy scheme was evaluated (Figure 1). A second analysis stratifying the sample according to treatment was performed. Toxicities included in this analysis were those associated with the main drug in the therapy scheme, according to the drug's prescribing information [2-5]. Only the genes associated with toxicity in previous studies were analyzed in each subgroup, according to the 'Variant Annotations' information provided by The Pharmacogenomics Knowledge Base [35]. In first line, 103 patients were treated with schemes containing 5FU, 84 patients with therapy based on capecitabine and 166 patients with oxaliplatin. In second line, 54 patients were treated with irinotecan based schemes (Figure 2).

\section{RESULTS}

\section{Patients Characteristics}

The total sample (first-line) included 194 patients that received 5FU, capecitabine, oxaliplatin or irinotecan based schemes. All patients were homozygous (no variant was found) for DPYD rs3918290, DPYD rs55886062 and UGT1A1 rs4148323, therefore they were not included in the association analysis. No variants were found in the Spanish population (Iberian Population in Spain, IBS) of The 1000 Genomes Project for these single nucleotide polymorphisms (SNPs) either [33]. Minor allele frequencies (MAF) were calculated and results are shown in Supplementary Table 1. All genes were in linkage disequilibrium (Supplementary Table 2). Most of the SNPs were in HardyWeinberg equilibrium, with the exception of $A B C B 1$ rs1045642 ( $p=0.0002852)$ and MTHFR rs1801131 ( $p=0.03836)$. No statistical differences with those described for the Iberian population [33] were found for either of these variants ( $A B C B 1$ rs1045642 T allele: 0.47 vs $0.46 ; p=0.8873$; 
MTHFR rs1801131 C allele: 0.35 vs $0.27 ; p=0.2213$ ). Baseline characteristics of the total sample and each subgroup of treatment patients are summarized in Table 1.

\section{Influence of clinical and genetic variables on treatment toxicity in first line of treatment}

Bonferroni adjusted $p$-value of 0.005 ( $0.05 / 10$ SNPs) was considered for bivariate analysis both in first and second line.

Hematological Toxicity. In the bivariate analysis, two variables tended to increase the toxicity risk: the DPYD rs17376848 AG genotype $\left(R R_{R E C}=2.28 ; C l 95 \%, 1.36-3.82 ; p=0.02665\right)$ and tumor localization in colon ( $R R=1.56 ; C 195 \%, 0.90-2.70 ; p=0.09761)$. In the multivariate analysis, the DPYD rs17376848 AG genotype increased hematological toxicity risk $\left(\mathrm{OR}_{\mathrm{REC}}=4.85 ; \mathrm{Cl} 95 \%, 1.23-23.65\right.$; $\mathrm{p}=0.0297)$.

Cardiovascular Toxicity. Patients with GSTP1 rs1695 G allele presented higher risk of cardiovascular toxicity (RRTREND=3.09; Cl95\%, 1.13-8.48; $\mathrm{p}=0.004486$ ), while the T allele of XRCC1 rs25487 showed a trend ( $\left.R R_{\text {TREND }}=3.02 ; C 195 \%, 1.03-8.83 ; p=0.04015\right)$. The independent association of GSTP1 rs1695 $G$ allele with higher cardiovascular toxicity risk was confirmed in multivariate analysis $\left(\mathrm{OR}_{\mathrm{TREND}}=4.05\right.$; Cl95\%, 1.40-13.50; $\mathrm{p}=0.0129$ ).

Neurological Toxicity. ECOG 0 patients had a greater risk of neurological toxicity ( $R R=1.48, C l 95 \%$, 1.05-2.09; $p=0.004287)$. Other risk factors were adenocarcinoma ( $R R=1.52, C \mid 95 \%, 1.09-2.13$; $\mathrm{p}=0.01639)$ and younger age at diagnosis (61.01 [56.05-66.24] vs 70.21 [61.64-74.78] years; $\left.\mathrm{p}=1.8 \cdot 10^{-05}\right)$. Patients with CC genotype for MTHFR rs1801133 (RR $\mathrm{DOM}_{\mathrm{DO}}=1.19 ; \mathrm{Cl95 \%}$, 0.98-1.43; $\mathrm{p}=0.05093)$ or ERCC1 rs11615 GG genotypes $\left(\mathrm{RR}_{\mathrm{REC}}=1.20 ; \mathrm{Cl} 95 \%, 1.03-1.39 ; \mathrm{p}=0.07193\right)$ showed higher toxicity risk trends. Multivariate analysis confirmed the protective effect of older age (OR=0.92, Cl95\%, 0.89-0.97; $\mathrm{p}=0.000417$ ) and the adenocarcinoma histopathology as risk factor for neurological toxicity $(\mathrm{OR}=4.22, \mathrm{Cl} 95 \%, 1.45-12.45 ; \mathrm{p}=0.007827)$. An interaction between histopathology and age was found, showing that patients with adenocarcinoma and older age had a lower risk of neurological toxicity ( $\mathrm{OR}=0.89, \mathrm{Cl} 95 \%, 0.82-0.97 ; \mathrm{p}=0.00798)$. ERCC1 rs11615 GG genotype $\left(\mathrm{OR}_{\mathrm{REC}}=3.98 ; \mathrm{Cl} 95 \%, 1.17-19.38 ; \mathrm{p}=0.047893\right)$ was also associated with an increased toxicity.

Cutaneous Toxicity. Women ( $R R=1.42 ; C l 95 \%, 1.02-1.98 ; \mathrm{p}=0.04153)$ and patients with tumor localization in colon ( $R R=1.87 ; \mathrm{Cl} 95 \%, 1.15-3.03 ; \mathrm{p}=0.004654)$ showed higher cutaneous toxicity risk. The GSTP1 rs1695 G allele ( $R_{\text {TREND }}=1.54$; $\left.C 195 \%, 1.13-2.10 ; p=0.008009\right)$ and the GG genotype of ERCC1 rs3212986 (RR $\left.\mathrm{ROM}_{\mathrm{DOM}}=1.50 ; \mathrm{Cl95 \%}, 1.07-2.10 ; \mathrm{p}=0.01798\right)$ showed a trend to increased cutaneous toxicity. The XRCC1 rs1799782 T allele (RRTREND $=0.50, C 195 \%, 0.23-1.10 ; p=0.04551$ ) 
showed a trend to reduced cutaneous toxicity. Tumor location in colon (OR=2.63; Cl95\%, 1.30-5.54; $\mathrm{p}=0.00847)$, as well as $\mathrm{G}$ allele of GSTP1 rs1695 (ORTREND $=1.81 ; \mathrm{Cl} 95 \%, 1.52-2.89 ; \mathrm{p}=0.01$ 113), were confirmed as risk factors for cutaneous toxicity in the multivariate analysis, while the T allele of XRCC1 rs1799782 was confirmed as protective factor ( $\left.\mathrm{OR}_{\mathrm{TREND}}=0.31 ; \mathrm{Cl} 95 \%, 0.10-0.82 ; \mathrm{p}=0.029\right)$. Asthenia. The GG genotype for ERCC1 rs11615 and the T allele for MTHFR rs1801133 showed a tendency to increase the risk of suffering from asthenia $\left(R R_{R E C}=1.77, C l 95 \%, 1.23-2.54 ; p=0.007205\right)$; $\left(R R_{T R E N D}=1.24 ; C l 95 \%, 0.96-1.60 ; p=0.09112\right)$. In multivariate analysis, only the effect of ERCC1 rs11615 GG genotype on asthenia was confirmed ( $\left.O R_{R E C}=2.91, C I 95 \%, 1.32-6.64 ; p=0.00894\right)$.

Respiratory Toxicity. It occurred more frequently in women ( $R R=2.76 ; C l 95 \%, 1.05-7.27 ; p=0.03176)$, in younger patients (57.57 [53.08-61.56] vs 63.09 [57.02-69.72] years; $p=0.0342)$, and those carrying the $\mathrm{G}$ allele of GSTP1 rs1695 (RR $\mathrm{RREND}_{\mathrm{T}}=2.63 ; \mathrm{Cl95 \%}, 1.36-5.08 ; \mathrm{p}=0.004281$ ) or the $\mathrm{G}$ allele of DPYD rs17376848 (RR TREND=5.97; Cl95\%, 1.43-24.85; $\mathrm{p}=0.00363)$. MTHFR rs1801133 T allele showed a tendency to increase the risk of respiratory toxicity $\left(R R_{T R E N D}=1.88 ; C l 95 \%, 0.97-3.67 ; p=0.04628\right)$, as did the TT genotype of ERCC1 rs3212986 ( $\left.R R_{R E C}=2.93 ; C l 95 \%, 1.05-8.18 ; p=0.06406\right)$. In the multivariate analysis, MTHFR rs1801133 T allele $\left(\mathrm{OR}_{\mathrm{TREND}}=2.51 ; \mathrm{Cl} 95 \%, 1.32-6.64 ; \mathrm{p}=0.00894\right)$, as well as the $G$ allele of GSTP1 rs1695 (ORTREND=3.01; Cl95\%, 1.43-6.72; $p=0.00469)$, were confirmed as risk factors for increased respiratory toxicity risk.

Bivariate analysis in first treatment line are shown in Supplementary Table 3 (clinicopathological characteristics) and Supplementary Table 4 (SNPs). Table 2 shows the multivariate analysis.

\section{Clinical and genetic variables influence on treatment toxicity in second line of treatment}

Asthenia. Patients in stages III-IV ( $R R=0.17 ; C \mid 95 \%, 0.03-0.83 ; \mathrm{p}=0.014)$ or carrying the XRCC1 rs1799782 T allele $\left(R R_{T R E N D}=0.35 ; C l 95 \%, 0.09-1.27 ; p=0.05764\right)$ had less risk of asthenia. These protective effects were both confirmed in the multivariate analysis $(\mathrm{OR}=0.08 ; \mathrm{Cl} 95 \%, 0.004-0.43$; $\mathrm{p}=0.0168) ;\left(\mathrm{OR}_{\text {TREND }}=0.17 ; \mathrm{Cl} 95 \%, 0.03-0.69 ; \mathrm{p}=0.0291\right)$.

Neurological Toxicity. Patients with larger tumor size experienced more toxicity (5.50 [3.87-7.17] vs 4.15 [3.05-5.00] cm; $p=0.02061)$, while being female was a protective factor ( $R R=0.42, C 195 \%, 0.17$ 1.00; $p=0.045)$. In the multivariate analysis, only larger tumor size was confirmed as a risk factor for neurological toxicity (OR=1.36, Cl95\%, 1.07-1.80; $\mathrm{p}=0.01652$ ).

Gastrointestinal Toxicity. XRCC1 rs25487 C allele increased toxicity risk (RR $R_{\text {TREND }}=2.19$; Cl95\%, 1.253.84; $p=0.003465)$, while GSTP1 rs1695 G allele (RRTREND $=0.79 ; C 195 \%, 0.60-1.03 ; p=0.04375)$ and MTHFR rs1801131 CC genotype showed a tendency to decrease it $\left(\mathrm{RR}_{\mathrm{REC}}=0.64 ; \mathrm{Cl}\right.$ ) $\%$, 0.33-1.24; $\mathrm{p}=0.08628$ ). In the multivariate analysis, the XRCC1 $\mathrm{rs} 25487 \mathrm{~T}$ allele was confirmed as a risk factor 
for gastrointestinal toxicity.

Cutaneous Toxicity. The AA genotype of ERCC1 rs11615 showed a tendency to increased cutaneous toxicity $\left(R R_{\mathrm{DOM}}=1.56 ; \mathrm{Cl} 95 \%, 0.90-2.72 ; \mathrm{p}=0.09519\right)$, which was not confirmed in multivariate analysis.

Infusional Reaction. Patients with T allele for XRCC1 rs1799782 experienced an increased risk of infusional reaction, but without being significant after Bonferroni correction (RRTREND $=3.87 ; \mathrm{Cl} 95 \%$, 1.38-10.84; $p=0.0157)$.

Cardiovascular Toxicity. The AA genotype of ERCC1 rs11615 showed a tendency to decrease the risk of cardiovascular toxicity $\left(R_{\mathrm{DOM}}=0.14 ; \mathrm{Cl} 95 \%, 0.02-1.15 ; \mathrm{p}=0.07654\right)$.

Hematological toxicity. The CC genotype of XRCC1 rs1799782 increased the risk of hematological toxicity $\left(\mathrm{RR}_{\mathrm{DOM}}=2.09 ; \mathrm{Cl95 \%}, 1.06-4.12 ; \mathrm{p}=0.09903\right)$, although not significantly after Bonferroni correction.

Bivariate analysis in patients in second-line of treatment are shown in Supplementary Table 5 (clinicopathological characteristics) and Supplementary Table 6 (SNPs). Multivariate analysis for second line of treatment is shown in Table 2.

\section{Clinical and genetic variables influence on treatment toxicity with 5-Fluorouracil in first line}

Bonferroni adjusted p-value of 0.01 ( $0.05 / 5 \mathrm{SNPs})$ was considered as significant for bivariate analysis in both $5 \mathrm{FU}$ and capecitabine treatment groups.

Grade 3-4 Toxicity. Tumor location in rectum showed a tendency to increase risk of grade 3-4 toxicity during treatment with $5 \mathrm{FU}(\mathrm{RR}=2.45 ; \mathrm{Cl} 95 \%, 0.81-7.41 ; \mathrm{p}=0.07505)$.

Modification of treatment. Women ( $R R=1.32 ; C l 95 \%, 1.02-1.72 ; p=0.0428)$ and patients whose tumors were located in rectum ( $R R=1.86 ; C I 95 \%, 1.11-3.12 ; p=0.001912)$ needed more modifications during treatment. The T allele of $A B C B 1$ rs1045642 tended to decrease the need of treatment modifications with 5FU ( $\left.R_{\text {TREND }}=0.86 ; \mathrm{Cl} 55 \%, 0.71-1.05 ; \mathrm{p}=0.0720\right)$. This association $\left(O R_{\text {TREND }}=3.06 ; \mathrm{Cl} 95 \%, 1.32-7.69 ; \mathrm{p}=0.012073\right)$ was confirmed in multivariate analysis, along with rectal cancer ( $\mathrm{OR}=6.51, \mathrm{Cl} 95 \%, 2.24-20.67 ; \mathrm{p}=0.000844)$.

Gastrointestinal Toxicity. In the bivariate analysis, only trends were obtained; older patients and those with $A B C B 1$ rs1045642 CC genotype showed a trend to increased gastrointestinal risk (60.9 [56.4-64.5] vs 58.4 [51.5-63.6] years; $p=0.09109) ;\left(R R_{D O M}=1.29 ; C l 95 \%, 1.05-1.59 ; p=0.0643\right)$. Age of patients and $A B C B 1$ rs 1045642 CC genotype were furtherly confirmed as gastrointestinal toxicity risk factors during $5 \mathrm{FU}$ treatment by multivariate analysis ( $\mathrm{OR}=1.06 ; \mathrm{Cl} 95 \%, 1.01-1.13 ; \mathrm{p}=0.0369$ ); $\left(\mathrm{OR}_{\text {DOM }}=5.80 ; \mathrm{Cl} 95 \%, 1.40-40.37 ; \mathrm{p}=0.0320\right)$. 
Respiratory toxicity. Larger tumor size and different histopathology from adenocarcinoma were risk factors for respiratory toxicity during treatment with $5 \mathrm{FU}(7.0[6.0-10.0]$ vs $4.5[3.5-6] \mathrm{cm}$; $p=0.02117) ;(R R=0.10, C \mid 95 \%, 0.02-0.42 ; p=0.009267)$. In multivariate analysis, both histopathology adenocarcinoma (OR=0.11, $\mathrm{Cl} 95 \%, 0.01-1.10 ; \mathrm{p}=0.036079)$ and smaller tumor size (OR=0.63, $\mathrm{Cl} 95 \%$, 0.39-0.95; $p=0.036079$ ) were confirmed as protective factors for respiratory toxicity.

Infusional reaction. Tumor size was related to experiencing an infusional reaction risk during 5FU treatment (7.0 [4.0-8.7] vs $4.5[3.5-5.9] ; p=0.03833)$.

Hematological Toxicity. The DPYD rs17376848 AG genotype increased the risk of experiencing haematological toxicity during treatment with $5 F U\left(R R_{R E C}=2.76 ; C l 95 \%, 2.11-3.62 ; p=0.00322\right)$.

Bivariate analysis is shown in Supplementary Table 7 and multivariate analysis in Table 3.

\section{Clinical and genetic variables influence on treatment toxicity with Capecitabine in first line}

Grade 3-4 Toxicity. Women experienced less high-grade toxicities during treatment with capecitabine ( $R R=0.37 ; C \mid 95 \%, 0.14-0.98 ; p=0.02582$ ). Patients carrying the $C C$ genotype in $A B C B 1$ rs1045642 had lower risk of toxicity 3-4 (RR $\left.R_{D O M}=0.31 ; C I 95 \%, 0.08-1.19 ; p=0.04444\right)$. Female gender was associated with grade 3-4 toxicity during treatment with capecitabine in multivariate analysis (OR=0.27; Cl95\%, 0.07-0.85; $\mathrm{p}=0.037$ ).

Modification of treatment. Only two trends were obtained: the TT genotype of $A B C B 1$ rs1045642 reduced the risk of treatment modifications $\left(R_{\mathrm{REC}}=0.58 ; \mathrm{Cl} 95 \%, 0.28-1.20 ; \mathrm{p}=0.0767\right)$, whereas the CC genotype of MTHFR rs1801131 increased it ( $\left.R_{R E C}=1.50 ; C I 95 \%, 1.05-2.15 ; p=0.07181\right)$.

Respiratory Toxicity. Being a woman ( $R R=4.10 ; C 195 \%, 1.15-14.66 ; \mathrm{p}=0.03115)$ and being younger (58.0 [56.2-60.5] vs 69.5 [62.1-73.0] years; $p=0.003536)$ were risk factors for respiratory toxicity during treatment with capecitabine. Patients carrying the T allele of MTHFR rs1801133 showed a tendency to increased risk $\left(R R_{T R E N D}=1.81 ; C l 95 \%, 0.79-4.14 ; p=0.02704\right)$. Female gender and age were confirmed, in the multivariate analysis, as risk factors for respiratory toxicity during treatment with capecitabine $(\mathrm{OR}=4.78 ; \mathrm{Cl} 95 \%, 1.11-25.54 ; \mathrm{p}=0.0435) ;(\mathrm{OR}=1.10 ; \mathrm{Cl} 95 \%, 1.02-1.20 ; \mathrm{p}=0.0148)$. Cutaneous toxicity. Patients with colon cancer experienced more cutaneous toxicity than those with rectal cancer ( $R R=1.88 ; C l 95 \%, 0.97-3.61 ; p=0.04013)$.

Infusional reaction. Women experienced infusional reaction more frequently during treatment ( $R R=2.76 ; C l 95 \%, 1.20-6.34 ; p=0.01269)$.

Cardiovascular toxicity. Women experienced more cardiovascular toxicity than men (RR=2.96; Cl95\%,2.17-4.05; $\mathrm{p}=0.01922$ ).

Asthenia. The CC genotype of MTHFR rs1801131 was found to be a risk factor for asthenia 
$\left(R_{R E C}=3.48 ; C l 95 \%, 1.81-6.66 ; p=0.009395\right)$.

Bivariate and multivariate analyses can be found in Supplementary Table 8 and Table 3, respectively.

\section{Clinical and genetic variables influence on treatment toxicity with Oxaliplatin in first line}

Bonferroni adjusted p-value of 0.008 (0.05/6 SNPs) was considered as significant threshold for bivariate analysis.

Grade 3-4 Toxicity. An advanced ECOG showed a trend to lower toxicity grade 3-4 (RR=0.55; Cl95\%, 0.32-0.94; $p=0.05074$ ) and the GG genotype of GSTP1 rs1695 with the increased risk ( $R R_{\text {DOM }}=1.61$; Cl95\%, 0.98-2.64; $\mathrm{p}=0.05566)$, although none of them were significant.

Modification of treatment. Patients with colon cancer needed more treatment modifications than those with rectal cancer ( $R R=1.59 ; C 195 \%, 1.16-2.19 ; p=0.0005318)$. The TT genotype of $A B C B 1$ rs1045642 showed a tendency to reduce the need to adjust the treatment $\left(R_{R E C}=0.67 ; C I 95 \%, 0.43-\right.$ $1.04 ; p=0.02556$ ). In multivariate analysis, patients with colon cancer needed more modifications in their treatment than those patients with rectal cancer (OR=3.74; Cl95\%, 1.79-7.96; $p=0.000495)$, whereas patients who presented the TT genotype of $A B C B 1$ rs1045642 needed fewer changes $\left(O R_{R E C}=0.32 ; C 195 \%, 0.12-0.82 ; p=0.018370\right)$. The percentage of patients carrying the TT genotype that required modification was not different regardless the use of FOLFOX or XELOX in first line (53.48 vs $40 \% ; p=0.5$ ).

Infusional Reaction. Female gender was associated with increased risk of infusional reaction during treatment with oxaliplatin ( $R R=1.62 ; C 195 \%, 0.92-2.87 ; p=0.09564)$, although it was not significant. Respiratory Toxicity. Age (60.9 [55.1-66.2] vs 64.6 [57.6-70.2]; $\mathrm{p}=0.02921)$, female gender ( $R R=3.25$; $\mathrm{Cl} 95 \%, 1.16-9.05 ; \mathrm{p}=0.01681)$ and the $\mathrm{G}$ allele of GSTP1 rs1695 $\left(\mathrm{RR}_{\mathrm{TREND}}=2.04 ; \mathrm{Cl} 95 \%, 0.96-4.37\right.$; $p=0.003047$ ) were associated with an increased risk of respiratory toxicity. The GG genotype of GSTP1 rs1695 ( $\left.R_{R E C}=3.94 ; C l 95 \%, 1.52-10.25 ; \mathrm{p}=0.01503\right)$ and the TT genotype of $E R C C 1 \mathrm{rs} 3212986$ showed a tendency to increase the risk of respiratory toxicity $\left(R_{R E C}=2.87 ; C I 95 \%, 1.02-8.07\right.$; $p=0.04715)$, while the AA genotype of GSTP1 rs1695 showed a tendency to decrease it $\left(R R_{D O M}=0.24\right.$; CI95\%, 0.07-0.83; $p=0.0127)$. In multivariate analysis, the GG genotype of GSTP1 rs1695 was found to be a risk factor for respiratory toxicity during treatment with oxaliplatin $\left(\mathrm{OR}_{\mathrm{REC}}=5.07 ; \mathrm{Cl} 95 \%, 1.41\right.$ 16.8; $p=0.00879$ ).

Asthenia. Only trends were obtained; the diagnosis of colon cancer (RR=1.52; Cl95\%, 0.93-2.46; $\mathrm{p}=0.07184)$, the GG genotype of ERCC1 $\mathrm{rs} 11615\left(\mathrm{RR}_{\mathrm{REC}}=1.74 ; \mathrm{Cl} 95 \%, 1.21-2.52 ; \mathrm{p}=0.009538\right)$ and the TT genotype of ERCC1 rs3212986 $\left(\mathrm{RR}_{\mathrm{REC}}=1.61 ; \mathrm{Cl} 95 \%, 1.05-2.46 ; \mathrm{p}=0.06031\right)$ tended to increase the risk of asthenia. In the multivariate analysis, patients homozygous for ERCC1 rs11615 G allele 
experienced increased risk of asthenia compared to heterozygous or homozygous for the A allele $\left(\mathrm{OR}_{\mathrm{REC}}=3.01 ; \mathrm{Cl} 95 \%, 1.30-7.32 ; \mathrm{p}=0.0118\right)$.

Neurological Toxicity. A histopathology of adenocarcinoma tumor showed a tendency to increase the risk of neurological toxicity ( $R R=1.26 ; C \mid 95 \%, 0.90-1.76 ; p=0.0659$ ).

Bivariate analysis for patients who included oxaliplatin in their treatment are detailed in Supplementary Table 9, while multivariate analysis is shown in Table 3.

\section{Clinical and genetic variables influence on treatment toxicity with Irinotecan in second line}

Five SNPs were analyzed: $A B C B 1$ rs1045642, XRCC1 rs25487, XRCC1 rs1799782, ERCC1 rs11615 and ERCC1 rs3212986. Therefore, a p-value adjusted by Bonferroni of $0.01(0.05 / 5)$ was taken for bivariate analysis. In multivariate analysis, the threshold for a significant p-value was 0.05 .

In the bivariate analysis of this treatment subgroup (54 patients), only tendencies were found (Supplementary Table 10). No independent association was found in multivariate analysis.

Grade 3-4 Toxicity. Patients homozygous for the T allele of $X R C C 1$ rs $25487\left(R_{R E C}=2.44 ; C 195 \%, 0.99-\right.$ 6.04; $p=0.0842$ ) tended to experience more grade $3-4$ toxicity, while those with the $G$ allele of $E R C C 1$ rs11615 showed a tendency to experience lower grade toxicities $\left(R_{T R E N D}=0.51 ; C l 95 \%, 0.22-1.16\right.$; $\mathrm{p}=0.0761$ ).

Modification of treatment. Patients with the TT genotype of XRCC1 rs25487 showed a tendency to more treatment modifications $\left(\mathrm{RR}_{\mathrm{REC}}=1.67 ; \mathrm{Cl} 95 \%, 1.31-2.12 ; \mathrm{p}=0.04032\right)$.

Gastrointestinal Toxicity. Patients in advanced stages of disease showed a tendency to experience less gastrointestinal toxicity ( $R R=0.56 ; C l 95 \%, 0.24-1.35 ; p=0.0914)$.

Hematological Toxicity. Patients carrying the T allele of $A B C B 1$ rs 1045642 showed a tendency to experienced less hematological toxicity during treatment with irinotecan $\left(R_{\mathrm{TREND}}=0.55 ; \mathrm{Cl95 \%}, 0.27\right.$ 1.12; $\mathrm{p}=0.06919)$.

Asthenia. The CC genotype of $X R C C 1 \mathrm{rs} 1799782$ showed a tendency to increase the risk $\left(\mathrm{RR}_{\mathrm{DOM}}=4.74\right.$;

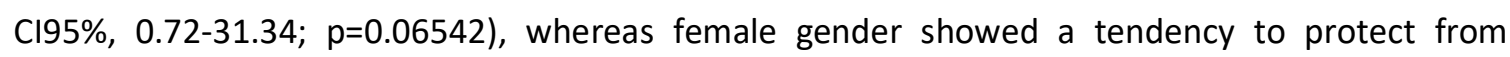
suffering asthenia ( $R R=4.74 ; C 195 \%, 0.72-31.34 ; p=0.06542)$.

Neurological Toxicity. Patients with the T allele of XRCC1 rs 25487 showed a tendency to have a lower risk of neurological toxicity $\left(R_{T R E N D}=0.18 ; C l 95 \%, 0.02-1.35 ; p=0.07869\right)$.

\section{DISCUSSION}

Toxicity degree 3-4 is de most frequently outcome in the literature. We analyzed all grades of toxicity 
and modification of treatment was also evaluated (dose reduction, delay or suspension due to toxicity) to make sure that no toxicity that could influence the treatment was left out.

$D P Y D$ is the gene that encodes dihydropyrimidine dehydrogenase (DPD), the enzyme responsible for the hepatic metabolism of 5FU and capecitabine. The variants that deeply decrease the enzyme activity are rs3918290 (DPYD*2A), rs55886062 (DPYD*13) and rs67376798, while the effect of rs17376848 results in a moderate reduction [14]. In the Spanish population (Iberian Population in Spain, IBS) represented in The 1000 Genomes Project, variant alleles for rs3918290, rs55886062 and rs67376798 are not found and the frequency of the rs 17376848 variant is nearly rare $(0.0187,4 / 214)$ [33]. In our study, none of the 194 patients were carriers of rs3918290 and rs55886062 variants, whereas we found two patients with the rs67376798 variant; unfortunately, this finding was insufficient to find associations with the risk of toxicity. However, the nine carriers found for rs17376848 variant had an increased risk of hematological toxicity, both in the overall first line group $\left(O R_{R E C}=4.85 ; \mathrm{Cl} 95 \%, 1.23-23.65 ; \mathrm{p}=0.03\right)$ and in the subgroup treated with $5 \mathrm{FU}\left(\mathrm{RR}_{\mathrm{REC}}=2.76 ; \mathrm{Cl} 95 \%\right.$, 2.11-3.62; $p=0.003)$. Among the six patients treated with FOLFOX, two developed neutropenia, one thrombocytopenia and another one experienced both neutropenia and thrombocytopenia during treatment. Only in one case of neutropenia, the grade was considered severe (3). No association was obtained in the capecitabine subgroup, maybe because only two of the nine carriers found for rs17376848 variant allele were in this group. One of them received neither 5FU nor capecitabine in their treatment, so it was not taken into account. Our findings are in agreement with those obtained by other authors. A study of 64 Italian patients found the AG genotype of rs17376848 associated with grade 3-4 toxicity to capecitabine, irinotecan and oxaliplatin ( $\mathrm{COI}$ scheme), (OR=14.53; Cl95\%, 1.36-155.20; $p=0.03$ )[7]. Teh et al. [9] also associated the $G$ allele of $r s 17376848$ with the risk of neutropenia during treatment with $5 \mathrm{FU}$ in 26 patients of Asian origin (OR=2.3; Cl95\%, 1.01-5.09; $\mathrm{p}=0.02$ ). In Asian countries, the frequency of this variant is higher ( 0.1212 for the Chinese population and 0.1202 for the Japanese population) [33], which could explain the result despite the small sample. Kristensen [8] obtained a similar result in 68 European colon cancer patients where the variant was related to higher risk of toxicity to $5 \mathrm{FU}$ and capecitabine $(R R=6 ; p=0.01)$. On the other hand, subsequent studies conducted in the populations of two clinical trials (CAIRO2, 508 patients and TOSCA, 100 patients) did not associate the AG genotype of rs 17376848 with the risk of severe toxicity during treatment with $5 \mathrm{FU}$ or capecitabine (RR=0.9; $C 195 \%, 0.3-3.0 ; p=0.9)[36]$; (OR=1.34;

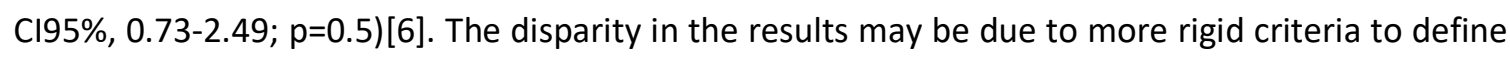
a toxic event as severe used in clinical trials, compared to smaller studies, resulting probably in 
leaving out toxic events due to the moderate effect of DPYD-rs17376848 on DPD activity. The ATP-binding cassette sub-family $B$ member 1 ( $A B C B 1$ ) is a transport protein, encoded by $A B C B 1$ gene [15], expels xenobiotics (as toxins or drugs) previously absorbed. Some tumor cells overexpress a large amount $A B C B 1$, which is an important cause of the multiresistance of some tumors to chemotherapy $[16,17]$. In our study, patients treated with 5FU carrying the T allele of rs1045642 required treatment adjustment due to toxicity ( $O R=3.06$; $C 195 \%, 1.32-7.69 ; p=0.01$ ), whereas in the group treated with Oxaliplatin, a smaller number of patients with the TT genotype needed adjustment of the treatment $(\mathrm{OR}=0.32 ; \mathrm{C} \mid 95 \%, 0.12-0.82 ; \mathrm{p}=0.02)$. This result, a priori, may be meaningless, since in the treatment group with 5FU, 97\% (100/103) of the patients were treated with both drugs in combination (FOLFOX). However, in the oxaliplatin treatment group, in addition to the 100 patients undergoing treatment with FOLFOX, 64 patients under treatment with XELOX were also analyzed and this "protective effect" seemed to be related to XELOX scheme, since in the Capecitabine group (where there was no FOLFOX), a similar result was obtained ( $R R=0.58, C 195 \%$, $0.28-1.20 ; p=0.08$ ) although did not become significant. To verify this hypothesis, we also compared the percentage of treatments in the first line with FOLFOX or with XELOX of patients carrying the $\Pi$ genotype that required modification ( 53.48 vs $40 \% ; p=0.5$ ), although there was no difference, so to elucidate this, a larger sample would be needed. There was also an association between the CC genotype and the risk of gastrointestinal toxicity during treatment with $5 \mathrm{FU}(\mathrm{OR}=5.80,95 \% \mathrm{Cl}, 1.40$ 40.37; $p=0.03)$. Other authors $[19,20]$ have linked the CC genotype with the lower incidence of diarrhea during treatment based on irinotecan ( $R R=0.27$; $C 195 \%, 0.16-1.03 ; p=0.04) ;(O R=0.162$; Cl95\%, 0.031-0.844; $p=0.03$ ).

In theory, by reducing the activity of the enzyme that is encoded, polymorphisms in the MTHFR gene would enhancing both the effect and the toxicity of fluoropyrimidines [37]. Our results showed an association between the TT genotype of MTHFR rs1801133 and the higher risk of presenting a respiratory toxicity episode during the treatment in the first line $(O R=2.51 ; C I 95 \%, 1.10-6.10$; $p=0.03$ ). This result was only reflected in the subgroup of capecitabine treatment as a trend ( $R R=1.81 ; C 195 \%, 0.79-4.14 ; p=0.02$ ). No study has associated the rs1801133 polymorphism with capecitabine toxicity [37-39]. In agreement with this, the CT + TT genotypes were related to increased diarrhea risk (OR=2.14; CI95\%, 1.01-4.56; $\mathrm{p}=0.04)$, mucositis (OR=8.17; Cl95\%,1.25-53.61; $\mathrm{p}=0.03$ ) and neutropenia $(\mathrm{OR}=3.03 ; \mathrm{Cl} 95 \%, 1.39-6.60 ; \mathrm{p}=0.005)$ during treatment with $5 \mathrm{FU}$ in 161 patients of Asian origin [21]. Korean patients who carried the TT genotype were at greater risk of experiencing severe toxicity with FOLFOX than the CT and CC genotypes (OR=2.32; CI95\%, 1.19-4.55; 
$p=0.01$ )[29]. In contrast, in a study of 130 Italian patients, the CC genotype was associated with an increase in non-specific severe toxicity ( $O R=3.10 ; C l 95 \%, 1.21-7.94 ; p=0.04)$ [22]. Patients included in our study who carried the CC genotype of the MTHFR variant rs1801131 had a higher risk of asthenia during treatment with capecitabine $(O R=3.48 ; C l 95 \%, 1.81-6.66 ; p=0.009)$, consistent with the development of some episode of grade 2-3 toxicity during treatment with capecitabine (OR=0.06; $\mathrm{Cl} 95 \%, 0.01-0.3, \mathrm{p}<0.05)$, according to a small study of 54 patients [39]. Other studies have not found an effect of rs1801131 on the risk of experiencing severe toxicity (grades 3-4) $(22,37)$.

X-ray repair cross complementing 1 (XRCC1) and Excision Repair Cross-Complementing group 1 (ERCC1) are proteins encoded by the gene of the same name whose function is to repair DNA damaged by ionizing radiation and alkylating agents such as oxaliplatin and irinotecan $[23,24]$. Our results showed an association of the T allele of XRCC1 rs1799782 with the reduction of the risk of experiencing cutaneous toxicity in the first line of treatment (OR=0.31, Cl95\%, 0.10-0.82; $p=0.03$ ). This finding was not replicated in the stratification by treatment. In second line, the T allele of XRCC1

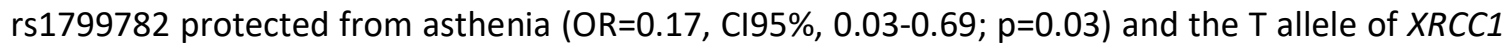
rs25487 increased gastrointestinal toxicity ( $\mathrm{OR}=3.03 ; \mathrm{Cl95 \% ,1.47-7.01;} \mathrm{p}=0.005$ ). Although over $60 \%$ of the second line treatments contained irinotecan, results in this subgroup remained as trends, probably due to the small sample size: the CC genotype of XRCC1 rs1799782 was associated with an increased risk of asthenia $(R R=4.74 ; C \mid 95 \%, 0.72-31.34 ; p=0.006542)$, the presence of the T allele of $X R C C 1$ rs25487 with severe toxicity $\left(R_{R E C}=2.44 ; C 195 \%, 0.99-6.04 ; p=0.08\right)$ and with less neurological toxicity $\left(R R_{T R E N D}=0.18 ; C l 95 \%, 0.02-1.35 ; p=0.08\right)$. The $C C$ genotype of $r s 25487$ had been associated with a lower risk of neuropathy during treatment with FOLFOX in 292 Asian patients (HR=0.56, Cl95\%, 0.32-0.99; $p=0.04$ ) [29]. However, McLeod and colleagues found no association between the XRCC1 variants and 114 patients treated with irinotecan, leucovorin and 5FU [18]. This is the first study to evaluate variant rs 1799782 in colorectal cancer, so the results cannot be compared with previous studies. In our study, patients with the GG genotype of ERCC1 rs11615 had a greater risk of asthenia, both in the first line $(O R=2.91 ; C 195 \%, 1.32-6.64 ; p=0.009)$, as the subgroup whose treatment contained oxaliplatin $(\mathrm{OR}=3.01 ; \mathrm{Cl} 95 \%, 1.30-7.32 ; \mathrm{p}=0.01)$. First-line patients also had a higher risk of neurological toxicity $(\mathrm{OR}=3.98 ; \mathrm{Cl} 95 \%, 1.17-19.38 ; \mathrm{p}=0.04)$, although this result was not reflected in any treatment subgroup. In the literature, ERCC1 rs11615 had been linked to the risk of neutropenia during treatment with oxaliplatin in Asian population (AA genotype; $O R=4.58$; $\mathrm{CI}$ (95\%, 1.20-17.40; $\mathrm{p}=0.026$ )[29] and in Spanish population (GG genotype; OR=0.20; $\mathrm{Cl95 \% ,0.06-}$ 
$0.69 ; p=0.01)[20]$.

GSTP1 (Glutathione S-Transferase) is an enzyme that plays an important role in the detoxification of xenobiotics, encoded in humans by GSTP1 gene [25]. Thierry Lecomte associated rs 1615 polymorphism to grade 3 neurotoxicity during oxaliplatin-based treatment in 64 patients of European origin (AA genotype; $\mathrm{OR}=5.54 ; \mathrm{Cl} 95 \%, 1.1-28.02 ; \mathrm{p}=0.03$ )[26] and there are other studies that have also suggested this association $[18,28]$. In our study, the GG genotype showed an association with higher risk of respiratory toxicity in the oxaliplatin group (OR=5.07; Cl95\%,1.4116.8; $p=0.009$ ), in agreement with the association of the $G$ allele with cardiovascular toxicity $(\mathrm{OR}=4.05 ; \mathrm{Cl} 195 \%, 1.40-13.50 ; \mathrm{p}=0.01)$, cutaneous (OR=1.81; $\mathrm{Cl} 95 \%, 1.52-2.89 ; \mathrm{p}=0.01$ ) and respiratory $(\mathrm{OR}=3.01 ; \mathrm{Cl} 95 \%, 1.43-6.72 ; \mathrm{p}=0.005)$ in the overall population treated in first line.

The majority of studies have been focused on the analysis of severe toxicity (grades 3-4), since they are the most clinically relevant toxic episodes and therefore the ones that are most interesting to predict. Hence the importance of finding genetic biomarkers, which can be easily assessed at the time of diagnosis, as they are constant over time. In the present study, both severe and any degree of toxicity experienced have been considered. None of the molecular biomarkers investigated were capable to predict grade 3-4 toxicity; however, some tendencies were shown, such as the AA genotype of rs1695 of GSTP1 in the oxaliplatin subgroup; the TT genotype of rs25487 of XRCC1 and the $\mathrm{G}$ allele of $E R C C 1$ rs11615 in the irinotecan subgroup; the CC genotype of $A B C B 1$ rs1045642 in the capecitabine subgroup. Regarding the need for treatment modification, patients with the $A B C B 1$ T allele for rs 1045642 required fewer treatment modifications in both the $5 \mathrm{FU}$ and the oxaliplatin group. Apart from the obtained associations, we observed some tendencies, like the $\Pi$ genotype of ABCB1 rs1045642 and the CC genotype of MTHFR rs1801131 in the capecitabine group and the TT genotype of XRCC1 rs25487 in the irinotecan subgroup. These data could serve as a basis for future studies with larger sample size that can elucidate whether these trends reflect true associations masked by a lack of power.

The main limitation of this study was the heterogeneity of treatment schemes given to patients, which is inherent to CRC therapy. The stratification in treatment subgroups, although provided a more homogeneous evaluation of the toxicities derived from each drug, supposed a loss of statistical power that may have derived in the lack of some associations. A larger sample size may have helped in this regard. Also, as any other retrospective study, the accuracy of the information was highly dependent on the exhaustiveness of the clinical records. 


\section{CONCLUSION}

$A B C B 1$ rs $1045642 \mathrm{~T}$ allele reduces the need for treatment modification with both 5FU and oxaliplatin. DPYD rs17376848, MTHFR rs1801131 and rs1801133, XRCC1 rs1799782 and rs25487, ERCC1 rs11615 and GSTP1 rs1695 polymorphisms are associated with different toxic effects during the chemotherapy treatment of CRC, although they cannot be considered as risk factors for severe toxicity (grades 3 and 4). No associations were found between gene polymorphisms DPYD rs67376798 and ERCC1 rs3212986 and chemotherapy toxicity. Our results show that although the genes studied cannot be considered as markers of severe toxicity, they are associated with toxicity and perhaps it would be convenient to take this into account

\section{REFERENCES}

[1] National Cancer Institute, Cáncer de colon (PDQ ${ }^{\circledR}$ )-Versión para profesionales de salud, 7 Marzo. (2017).

[2] AEMPS, Ficha Técnica Xeloda ${ }^{\circledR}$, (n.d.).

[3] AEMPS, Ficha técnica Irinotecán, (n.d.). https://cima.aemps.es/cima/pdfs/es/ft/81357/FT_81357.pdf.

[4] AEMPS, Ficha técnica Oxaliplatino, (n.d.). https://cima.aemps.es/cima/pdfs/es/ft/67390/FT_67390.pdf.

[5] AEMPS, Ficha técnica 5-FLUOROURACILO, (n.d.). https://cima.aemps.es/cima/pdfs/es/ft/71868/FT_71868.pdf.

[6] A. Ruzzo, F. Graziano, F. Galli, F. Galli, E. Rulli, S. Lonardi, M. Ronzoni, B. Massidda, V. Zagonel, N. Pella, C. Mucciarini, R. Labianca, M.T. Ionta, I. Bagaloni, E. Veltri, P. Sozzi, S. Barni, V. Ricci, L. Foltran, M. Nicolini, E. Biondi, A. Bramati, D. Turci, S. Lazzarelli, C. Verusio, F. Bergamo, A. Sobrero, L. Frontini, M. Menghi, M. Magnani, Dihydropyrimidine dehydrogenase pharmacogenetics for predicting fluoropyrimidine-related toxicity in the randomised, phase III adjuvant TOSCA trial in high-risk colon cancer patients, Br. J. Cancer. 117 (2017) 1269-1277. https://doi.org/10.1038/bjc.2017.289.

[7] F.S. Falvella, S. Cheli, A. Martinetti, C. Mazzali, R. lacovelli, C. Maggi, M. Gariboldi, M.A. Pierotti, M. Di Bartolomeo, E. Sottotetti, R. Mennitto, I. Bossi, F. De Braud, E. Clementi, F. Pietrantonio, DPD and UGT1A1 deficiency in colorectal cancer patients receiving triplet chemotherapy with fluoropyrimidines, oxaliplatin and irinotecan, Br. J. Clin. Pharmacol. 80 
(2015) 581-588. https://doi.org/10.1111/bcp.12631.

[8] M.H. Kristensen, P.L. Pedersen, G. V. Melsen, J. Ellehauge, J. Mejer, Variants in the dihydropyrimidine dehydrogenase, methylenetetrahydrofolate reductase and thymidylate synthase genes predict early toxicity of 5-fluorouracil in colorectal cancer patients, J. Int. Med. Res. 38 (2010) 870-883. https://doi.org/10.1177/147323001003800313.

[9] L.K. Teh, S. Hamzah, H. Hashim, Z. Bannur, Z.A. Zakaria, Z. Hasbullani, J.K.S. Shia, H. Fijeraid, A. Md Nor, M. Zailani, P. Ramasamy, H. Ngow, S. Sood, M.Z. Salleh, Potential of dihydropyrimidine dehydrogenase genotypes in personalizing, Ther. Drug Monit. 35 (2013) 624-630. https://doi.org/10.1097/FTD.0b013e318290acd2.

[10] A.M. Lee, Q. Shi, E. Pavey, S.R. Alberts, D.J. Sargent, F.A. Sinicrope, J.L. Berenberg, R.M. Goldberg, R.B. Diasio, DPYD variants as predictors of 5-fluorouracil toxicity in adjuvant colon cancer treatment (NCCTG N0147), J. Natl. Cancer Inst. 106 (2014) 1-12. https://doi.org/10.1093/jnci/dju298.

[11] A. Madi, D. Fisher, T.S. Maughan, J.P. Colley, A.M. Meade, J. Maynard, V. Humphreys, H. Wasan, R.A. Adams, S. Idziaszczyk, R. Harris, R.S. Kaplan, J.P. Cheadle, Pharmacogenetic analyses of 2183 patients with advanced colorectal cancer; potential role for common dihydropyrimidine dehydrogenase variants in toxicity to chemotherapy, Eur. J. Cancer. 102 (2018) 31-39. https://doi.org/10.1016/j.ejca.2018.07.009.

[12] T.K. Froehlich, U. Amstutz, S. Aebi, M. Joerger, C.R. Largiadèr, Clinical importance of risk variants in the dihydropyrimidine dehydrogenase gene for the prediction of early-onset fluoropyrimidine toxicity, Int. J. Cancer. 136 (2015) 730-739. https://doi.org/10.1002/ijc.29025.

[13] C.R.L. Didier Meulendijks*, Linda M Henricks*, Gabe S Sonke, Maarten J Deenen, Tanja K Froehlich, Ursula Amstutz, C.P. Barbara A Jennings, Anthony M Marinaki, Jeremy D Sanderson, Zdenek Kleibl, Petra Kleiblova, Matthias Schwab, Ulrich M Zanger, J.H.M.S. Ian Tomlinson, Eva Gross, André B P van Kuilenburg, Cornelis J A Punt, Miriam Koopman, Jos H Beijnen, Annemieke Cats, Clinical relevance of DPYD variants c . 1679T > G , c . 1236G > A / HapB3, and c. 1601G > A as predictors of severe fl uoropyrimidine-associated toxicity : a systematic review and meta-analysis of individual patient data, 2045 (2015) 1-12. https://doi.org/10.1016/S1470-2045(15)00286-7.

[14] U. Amstutz, L.M. Henricks, S.M. Offer, J. Barbarino, H.M. Jan, J.J. Swen, T.E. Klein, H.L. Mcleod, K.E. Caudle, Fluoropyrimidine Dosing : 2017 Update, 103 (2019) 210-216. 
https://doi.org/10.1002/cpt.911.Clinical.

[15] K. Uedat, D.P. Clarks, C. Chen, I.B. Roninsonll, M.M. Gottesmans, I. Pastan, The Human Multidrug Resistance, (1987) 505-508.

[16] J.R. Riordan, K. Deuchars, N. Kartner, N. Alon, J. Trent, V. Ling, Amplification of Pglycoprotein genes in multidrug-resistant mammalian cell lines., Nature. 316 (1985) 817819. https://doi.org/10.1038/316817a0.

[17] N. Kartner, D. Evernden-Porelle, G. Bradley, V. Ling, Detection of P-glycoprotein in multidrug-resistant cell lines by monoclonal antibodies., Nature. 316 (1985) 820-823. https://doi.org/10.1038/316820a0.

[18] H.L. McLeod, D.J. Sargent, S. Marsh, E.M. Green, C.R. King, C.S. Fuchs, R.K. Ramanathan, S.K. Williamson, B.P. Findlay, S.N. Thibodeau, A. Grothey, R.F. Morton, R.M. Goldberg, Pharmacogenetic predictors of adverse events and response to chemotherapy in metastatic colorectal cancer: Results from North American Gastrointestinal Intergroup Trial N9741, J. Clin. Oncol. 28 (2010) 3227-3233. https://doi.org/10.1200/JCO.2009.21.7943.

[19] E. Gonzalez-Haba, M.I. García, L. Cortejoso, C. López-Lillo, N. Barrueco, P. García-Alfonso, S. Alvarez, J.L. Jiménez, M.L. Martín, M.A. Muñóz-Fernández, M. Sanjurjo, L.A. LpezFernández, $A B C B 1$ gene polymorphisms are associated with adverse reactions in fluoropyrimidine-treated colorectal cancer patients, Pharmacogenomics. 11 (2010) 17151723. https://doi.org/10.2217/pgs.10.159.

[20] L. Cortejoso, M.I. García, P. García-Alfonso, E. González-Haba, F. Escolar, M. Sanjurjo, L.A. López-Fernández, Differential toxicity biomarkers for irinotecan- and oxaliplatin-containing chemotherapy in colorectal cancer, Cancer Chemother. Pharmacol. 71 (2013) 1463-1472. https://doi.org/10.1007/s00280-013-2145-6.

[21] N.A. Nahid, M.N.H. Apu, M.R. Islam, S. Shabnaz, S.M. Chowdhury, M.U. Ahmed, Z. Nahar, M.S. Islam, M.S. Islam, A. Hasnat, DPYD*2A and MTHFR C677T predict toxicity and efficacy, respectively, in patients on chemotherapy with 5-fluorouracil for colorectal cancer, Cancer Chemother. Pharmacol. 81 (2018) 119-129. https://doi.org/10.1007/s00280-017-3478-3.

[22] M. Gusella, A.C. Frigo, C. Bolzonella, R. Marinelli, C. Barile, A. Bononi, G. Crepaldi, D. Menon, L. Stievano, S. Toso, F. Pasini, E. Ferrazzi, R. Padrini, Predictors of survival and toxicity in patients on adjuvant therapy with 5-fluorouracil for colorectal cancer, $\mathrm{Br}$. J. Cancer. 100 (2009) 1549-1557. https://doi.org/10.1038/sj.bjc.6605052.

[23] A.M. Sijbers, P.J. van der Spek, H. Odijk, J. van den Berg, M. van Duin, A. Westerveld, N.G. 
Jaspers, D. Bootsma, J.H. Hoeijmakers, Mutational analysis of the human nucleotide excision repair gene ERCC1., Nucleic Acids Res. 24 (1996) 3370-3380.

https://doi.org/10.1093/nar/24.17.3370.

[24] C.J. Whitehouse, R.M. Taylor, A. Thistlethwaite, H. Zhang, F. Karimi-Busheri, D.D. Lasko, M. Weinfeld, K.W. Caldecott, XRCC1 stimulates human polynucleotide kinase activity at damaged DNA termini and accelerates DNA single-strand break repair., Cell. 104 (2001) 107-117.

[25] J.A. Moscow, C.R. Fairchild, M.J. Madden, D.T. Ransom, H.S. Wieand, E.E. O’Brien, D.G. Poplack, J. Cossman, C.E. Myers, K.H. Cowan, Expression of anionic glutathione-Stransferase and P-glycoprotein genes in human tissues and tumors., Cancer Res. 49 (1989) $1422-1428$.

[26] T. Lecomte, B. Landi, P. Beaune, P. Laurent-Puig, M.A. Loriot, Glutathione S-transferase P1 polymorphism (Ile105Val) predicts cumulative neuropathy in patients receiving oxaliplatinbased chemotherapy, Clin. Cancer Res. 12 (2006) 3050-3056. https://doi.org/10.1158/1078-0432.CCR-05-2076.

[27] M. Agostini, L.M. Pasetto, S. Pucciarelli, S. Terrazzino, A. Ambrosi, C. Bedin, F. Galdi, M.L. Friso, C. Mescoli, E. Urso, A. Leon, M. Lise, D. Nitti, Glutathione S-transferase P1 lle105Val polymorphism is associated with haematological toxicity in elderly rectal cancer patients receiving preoperative chemoradiotherapy, Drugs and Aging. 25 (2008) 531-539. https://doi.org/10.2165/00002512-200825060-00006.

[28] A. Ruzzo, F. Graziano, F. Loupakis, D. Santini, V. Catalano, R. Bisonni, R. Ficarelli, A. Fontana, F. Andreoni, A. Falcone, E. Canestrari, G. Tonini, D. Mari, P. Lippe, F. Pizzagalli, G. Schiavon, P. Alessandroni, L. Giustini, P. Maltese, E. Testa, E.T. Menichetti, M. Magnani, Pharmacogenetic profiling in patients with advanced colorectal cancer treated with firstline FOLFIRI chemotherapy, Pharmacogenomics J. 8 (2008) 278-288. https://doi.org/10.1038/sj.tpj.6500463.

[29] K.H. Lee, H.J. Chang, S.W. Han, D.Y. Oh, S.A. Im, Y.J. Bang, S.Y. Kim, K.W. Lee, J.H. Kim, Y.S. Hong, T.W. Kim, Y.S. Park, W.K. Kang, S.J. Shin, J.B. Ahn, G.H. Kang, S.Y. Jeong, K.J. Park, J.G. Park, T.Y. Kim, Pharmacogenetic analysis of adjuvant FOLFOX for Korean patients with colon cancer, Cancer Chemother. Pharmacol. 71 (2013) 843-851. https://doi.org/10.1007/s00280-013-2075-3.

[30] H. Services, Common Terminology Criteria for Adverse Events ( CTCAE ), 2009 (2010). 
[31] S.B. Edge, C.C. Compton, The American Joint Committee on Cancer : the 7th Edition of the AJCC Cancer Staging Manual and the Future of TNM, (2010) 1471-1474. https://doi.org/10.1245/s10434-010-0985-4.

[32] C.C. Chang, C.C. Chow, L.C.A.M. Tellier, S. Vattikuti, S.M. Purcell, J.J. Lee, Second-generation PLINK: Rising to the challenge of larger and richer datasets, Gigascience. 4 (2015) 1-16. https://doi.org/10.1186/s13742-015-0047-8.

[33] A. Auton, G.R. Abecasis, D.M. Altshuler, R.M. Durbin, D.R. Bentley, A. Chakravarti, A.G. Clark, P. Donnelly, E.E. Eichler, P. Flicek, S.B. Gabriel, R.A. Gibbs, E.D. Green, M.E. Hurles, B.M. Knoppers, J.O. Korbel, E.S. Lander, C. Lee, H. Lehrach, E.R. Mardis, G.T. Marth, G.A. McVean, D.A. Nickerson, J.P. Schmidt, S.T. Sherry, J. Wang, R.K. Wilson, E. Boerwinkle, H. Doddapaneni, Y. Han, V. Korchina, C. Kovar, S. Lee, D. Muzny, J.G. Reid, Y. Zhu, Y. Chang, Q. Feng, X. Fang, X. Guo, M. Jian, H. Jiang, X. Jin, T. Lan, G. Li, J. Li, Y. Li, S. Liu, X. Liu, Y. Lu, X. Ma, M. Tang, B. Wang, G. Wang, H. Wu, R. Wu, X. Xu, Y. Yin, D. Zhang, W. Zhang, J. Zhao, M. Zhao, X. Zheng, N. Gupta, N. Gharani, L.H. Toji, N.P. Gerry, A.M. Resch, J. Barker, L. Clarke, L. Gil, S.E. Hunt, G. Kelman, E. Kulesha, R. Leinonen, W.M. McLaren, R. Radhakrishnan, A. Roa, D. Smirnov, R.E. Smith, I. Streeter, A. Thormann, I. Toneva, B. Vaughan, X. ZhengBradley, R. Grocock, S. Humphray, T. James, Z. Kingsbury, R. Sudbrak, M.W. Albrecht, V.S. Amstislavskiy, T.A. Borodina, M. Lienhard, F. Mertes, M. Sultan, B. Timmermann, M.L. Yaspo, L. Fulton, V. Ananiev, Z. Belaia, D. Beloslyudtsev, N. Bouk, C. Chen, D. Church, R. Cohen, C. Cook, J. Garner, T. Hefferon, M. Kimelman, C. Liu, J. Lopez, P. Meric, C. O’Sullivan, Y. Ostapchuk, L. Phan, S. Ponomarov, V. Schneider, E. Shekhtman, K. Sirotkin, D. Slotta, H. Zhang, S. Balasubramaniam, J. Burton, P. Danecek, T.M. Keane, A. Kolb-Kokocinski, S. McCarthy, J. Stalker, M. Quail, C.J. Davies, J. Gollub, T. Webster, B. Wong, Y. Zhan, C.L. Campbell, Y. Kong, A. Marcketta, F. Yu, L. Antunes, M. Bainbridge, A. Sabo, Z. Huang, L.J.M. Coin, L. Fang, Q. Li, Z. Li, H. Lin, B. Liu, R. Luo, H. Shao, Y. Xie, C. Ye, C. Yu, F. Zhang, H. Zheng, H. Zhu, C. Alkan, E. Dal, F. Kahveci, E.P. Garrison, D. Kural, W.P. Lee, W.F. Leong, M. Stromberg, A.N. Ward, J. Wu, M. Zhang, M.J. Daly, M.A. DePristo, R.E. Handsaker, E. Banks, G. Bhatia, G. Del Angel, G. Genovese, H. Li, S. Kashin, S.A. McCarroll, J.C. Nemesh, R.E. Poplin, S.C. Yoon, J. Lihm, V. Makarov, S. Gottipati, A. Keinan, J.L. Rodriguez-Flores, T. Rausch, M.H. Fritz, A.M. Stütz, K. Beal, A. Datta, J. Herrero, G.R.S. Ritchie, D. Zerbino, P.C. Sabeti, I. Shlyakhter, S.F. Schaffner, J. Vitti, D.N. Cooper, E. V. Ball, P.D. Stenson, B. Barnes, M. Bauer, R.K. Cheetham, A. Cox, M. Eberle, S. Kahn, L. Murray, J. Peden, R. Shaw, E.E. 
Kenny, M.A. Batzer, M.K. Konkel, J.A. Walker, D.G. MacArthur, M. Lek, R. Herwig, L. Ding, D.C. Koboldt, D. Larson, K. Ye, S. Gravel, A. Swaroop, E. Chew, T. Lappalainen, Y. Erlich, M. Gymrek, T.F. Willems, J.T. Simpson, M.D. Shriver, J.A. Rosenfeld, C.D. Bustamante, S.B. Montgomery, F.M. De La Vega, J.K. Byrnes, A.W. Carroll, M.K. DeGorter, P. Lacroute, B.K. Maples, A.R. Martin, A. Moreno-Estrada, S.S. Shringarpure, F. Zakharia, E. Halperin, Y. Baran, E. Cerveira, J. Hwang, A. Malhotra, D. Plewczynski, K. Radew, M. Romanovitch, C. Zhang, F.C.L. Hyland, D.W. Craig, A. Christoforides, N. Homer, T. Izatt, A.A. Kurdoglu, S.A. Sinari, K. Squire, C. Xiao, J. Sebat, D. Antaki, M. Gujral, A. Noor, K. Ye, E.G. Burchard, R.D. Hernandez, C.R. Gignoux, D. Haussler, S.J. Katzman, W.J. Kent, B. Howie, A. Ruiz-Linares, E.T. Dermitzakis, S.E. Devine, H.M. Kang, J.M. Kidd, T. Blackwell, S. Caron, W. Chen, S. Emery, L. Fritsche, C. Fuchsberger, G. Jun, B. Li, R. Lyons, C. Scheller, C. Sidore, S. Song, E. Sliwerska, D. Taliun, A. Tan, R. Welch, M.K. Wing, X. Zhan, P. Awadalla, A. Hodgkinson, Y. Li, X. Shi, A. Quitadamo, G. Lunter, J.L. Marchini, S. Myers, C. Churchhouse, O. Delaneau, A. Gupta-Hinch, W. Kretzschmar, Z. Iqbal, I. Mathieson, A. Menelaou, A. Rimmer, D.K. Xifara, T.K. Oleksyk, Y. Fu, X. Liu, M. Xiong, L. Jorde, D. Witherspoon, J. Xing, B.L. Browning, S.R. Browning, F. Hormozdiari, P.H. Sudmant, E. Khurana, C. Tyler-Smith, C.A. Albers, Q. Ayub, Y. Chen, V. Colonna, L. Jostins, K. Walter, Y. Xue, M.B. Gerstein, A. Abyzov, S. Balasubramanian, J. Chen, D. Clarke, Y. Fu, A.O. Harmanci, M. Jin, D. Lee, J. Liu, X.J. Mu, J. Zhang, Y. Zhang, C. Hartl, K. Shakir, J. Degenhardt, S. Meiers, B. Raeder, F.P. Casale, O. Stegle, E.W. Lameijer, I. Hall, V. Bafna, J. Michaelson, E.J. Gardner, R.E. Mills, G. Dayama, K. Chen, X. Fan, Z. Chong, T. Chen, M.J. Chaisson, J. Huddleston, M. Malig, B.J. Nelson, N.F. Parrish, B. Blackburne, S.J. Lindsay, Z. Ning, Y. Zhang, H. Lam, C. Sisu, D. Challis, U.S. Evani, J. Lu, U. Nagaswamy, J. Yu, W. Li, L. Habegger, H. Yu, F. Cunningham, I. Dunham, K. Lage, J.B. Jespersen, H. Horn, D. Kim, R. Desalle, A. Narechania, M.A.W. Sayres, F.L. Mendez, G.D. Poznik, P.A. Underhill, D. Mittelman, R. Banerjee, M. Cerezo, T.W. Fitzgerald, S. Louzada, A. Massaia, F. Yang, D. Kalra, W. Hale, X. Dan, K.C. Barnes, C. Beiswanger, H. Cai, H. Cao, B. Henn, D. Jones, J.S. Kaye, A. Kent, A. Kerasidou, R. Mathias, P.N. Ossorio, M. Parker, C.N. Rotimi, C.D. Royal, K. Sandoval, Y. Su, Z. Tian, S. Tishkoff, M. Via, Y. Wang, H. Yang, L. Yang, J. Zhu, W. Bodmer, G. Bedoya, Z. Cai, Y. Gao, J. Chu, L. Peltonen, A. Garcia-Montero, A. Orfao, J. Dutil, J.C. Martinez-Cruzado, R.A. Mathias, A. Hennis, H. Watson, C. McKenzie, F. Qadri, R. LaRocque, X. Deng, D. Asogun, O. Folarin, C. Happi, O. Omoniwa, M. Stremlau, R. Tariyal, M. Jallow, F.S. Joof, T. Corrah, K. Rockett, D. Kwiatkowski, J. Kooner, T.T. Hien, S.J. 
Dunstan, N. ThuyHang, R. Fonnie, R. Garry, L. Kanneh, L. Moses, J. Schieffelin, D.S. Grant, C. Gallo, G. Poletti, D. Saleheen, A. Rasheed, L.D. Brooks, A.L. Felsenfeld, J.E. McEwen, Y. Vaydylevich, A. Duncanson, M. Dunn, J.A. Schloss, A global reference for human genetic variation, Nature. 526 (2015) 68-74. https://doi.org/10.1038/nature15393.

[34] G.M. Clarke, C. a Anderson, F.H. Pettersson, L.R. Cardon, P. Andrew, Europe PMC Funders Group Basic statistical analysis in genetic case-control studies, Nat. Protoc. 6 (2011) 121133. https://doi.org/10.1038/nprot.2010.182.Basic.

[35] C.F. Thorn, T.E. Klein, R.B. Altman, PharmGKB : The Pharmacogenomics Knowledge Base, (2014) 311-320. https://doi.org/10.1007/978-1-62703-435-7.

[36] M.J. Deenen, J. Tol, A.M. Burylo, V.D. Doodeman, A. De Boer, A. Vincent, H.J. Guchelaar, P.H.M. Smits, J.H. Beijnen, C.J.A. Punt, J.H.M. Schellens, A. Cats, Relationship between single nucleotide polymorphisms and haplotypes in DPYD and toxicity and efficacy of capecitabine in advanced colorectal cancer, Clin. Cancer Res. 17 (2011) 3455-3468. https://doi.org/10.1158/1078-0432.CCR-10-2209.

[37] L.H. Van Huis-Tanja, H. Gelderblom, C.J.A. Punt, H.J. Guchelaar, MTHFR polymorphisms and capecitabine-induced toxicity in patients with metastatic colorectal cancer, Pharmacogenet. Genomics. 23 (2013) 208-218. https://doi.org/10.1097/FPC.0b013e32835ee8e1.

[38] B.A. Jennings, Y.K. Loke, J. Skinner, M. Keane, G.S. Chu, R. Turner, D. Epurescu, A. Barrett, G. Willis, Evaluating Predictive Pharmacogenetic Signatures of Adverse Events in Colorectal Cancer Patients Treated with Fluoropyrimidines, PLoS One. 8 (2013) 1-9. https://doi.org/10.1371/journal. pone.0078053.

[39] R. Sharma, J.M. Hoskins, L.P. Rivory, M. Zucknick, R. London, C. Liddle, S.J. Clarke, Thymidylate synthase and methylenetetrahydrofolate reductase gene polymorphisms and toxicity to capecitabine in advanced colorectal cancer patients, Clin. Cancer Res. 14 (2008) 817-825. https://doi.org/10.1158/1078-0432.CCR-07-0425.

\section{FIGURE LEGEND}

Figure 1. Study population divided by chemotherapeutic treatment line.

Figure 2. Study population stratifying by treatment subgroups and SNP analyzed in each subgroup. 
